\title{
Kearifan Lokal Pertanian, Permasalahan, dan Arahan Strategi dalam Pengelolaan Pertanian di Desa Sembungan
}

\author{
Rika Harini ${ }^{1}$ Dewi Nurul Aulia ${ }^{1}$, Erdeana Candra Ningrum ${ }^{1}$, Kurnun Hanifah $^{1}$, Laila Fitria ${ }^{1}$ dan Tania Dewanti ${ }^{1}$
}

${ }^{1}$ Department of Environmental Geography, Faculty of Geography, Universitas Gadjah Mada, Yogyakarta, Indonesia

\author{
Email koresponden: rikaharini@ugm.ac.id
}

Direvisi: 2020-06-02 Diterima: 2020-9-25

(C2020 Fakultas Geografi UGM dan Ikatan Geograf Indonesia (IGI)

\begin{abstract}
Abstrak Sektor pertanian merupakan sektor yang menjadi andalan perekonomian di Kabupaten Wonosobo, terutama di Desa Sembungan. Aktivitas pertanian di Desa Sembungan masih didasari dengan nilai-nilai kearifan lokal dalam proses penanaman, pengolahan ladang, sampai dengan panen. Permasalahan yang kemudian muncul adalah tidak semua kearifan lokal sesuai dengan nilainilai lingkungan yang harus dipenuhi untuk mengurangi dampak negatif pertanian. Penelitian dilakukan dengan metode kualitatif, pengamblan data dilakukan dengan wawancara mendalam, diskusi kelompok terarah, dan observasi lapangan. Hasil penelitian menunjukkan bahua kearifan lokal pertanian di Desa Sembungan meliputi tumpang sari, gotong royong, nyabuk gunung, dan selokan dalam. Namun dalam prakteknya beberapa kearifan lokal tidak sesuai dengan nilai-nilai lingkungan. Perubahan dari aspek teknis, juga edukasi dan pelatihan kepada petani dibutuhkan untuk dapat menyesuaikan kearifan lokal dengan nilai-nilai lingkungan untuk dapat mencapai pertanian ramah lingkungan.
\end{abstract}

Kata kunci : kearifan lokal, permasalahan, strategi

\begin{abstract}
Agriculture is the main economy sector in Wonosobo District, especially in Sembungan Village. Agriculture activities such as planting, land cultivation, and harvesting in Sembungan Village are still done based on local wisdom. The problem is not all local wisdom meet the environmental values which should be fulfilled to reduce the negative effects of agriculture. The research is conducted by qualitative method with in-depth interview, focus group discussion, and field observation. The results show that the agriculture local wisdom in Sembungan Village take form as tumpang sari, gotong royong, nyabuk gunung, and selokan dalam. However, in practice, some of locd wisdom do not meet the environmental values. Changes from technical aspect, also education and training for the farmers are needed to adjust the existing local wisdom to environmental values in order to achieve the environmental friendly-agriculture
\end{abstract}

\section{PENDAHULUAN}

Desa Sembungan merupakan salah satu desa di Kecamatan Kejajar, Kabupaten Wonosobo yang bergantung pada sektor pertanian. Sektor pertanian di kabupaten tersebut menyumbang Produk Domestik Regional Bruto (PDRB) terbesar yaitu $31,72 \%$ pada tahun 2015 dan meningkat menjadi $32,29 \%$ pada tahun 2016. Sub sektor pertanian terdiri dari tanaman pangan, hortikultura, hingga perkebunan dengan berbagai jenis komoditas yang beragam (BPS, 2017). Desa Sembungan adalah salah satu desa penghasil produksi kentang terbesar di Kabupaten Wonosobo. Hal ini dikarenakan suhu dan kondisi lingkungan yang cocok untuk penanaman jenis tanaman tersebut. Tanaman hortikultura, palawija, dan perkebunan dapat tumbuh dan berkembang dengan baik di desa tersebut. Berdasarkan Profil Desa Sembungan tahun 2016, jenis penggunaan lahan desa tersebut $75,31 \%$ merupakan tegalan. Kondisi lingkungan di desa ini cocok untuk pertanian tanaman hortikultura, dengan kentang sebagai komoditas unggulan (Arbangiyah, 2012).

Kearifan lokal merupakan kemampuan menyikapi dan memberdayakan potensi nilai-nilai luhur budaya setempat.
Oleh karena itu, kearifan lokal merupakan entitas yang sangat menentukan harkat dan martabat manusia dalam komunitasnya (Geertz, 1989). Pengelolaan pertanian dengan kearifan lokal yang baik dan benar di Desa Sembungan dapat mengurangi kegiatan pertanian yang tidak ramah lingkungan. Pelestarian dan proses pembinaan masyarakat tentang berbagai kearifan lokal di Desa Sembungan dalam mengelola pertanian perlu ditingkatkan dan diperkuat. Kearifan lokal yang benar perlu dilestarikan dalam kegiatan pertanian di Desa Sembungan dilakukan sehingga degradasi lingkungan dapat dihilangkan dan produktivitas pertanian menjadi meningkat. Terdapat beberapa jenis kearifan lokal di Desa Sembungan yang dilakukan oleh masyarakat. Kearifan lokal ini dapat dimaksimalkan dengan baik, selain untuk meningkatkan produktivitas dapat pula digunakan untuk menghindari kerusakan lingkungan yang lebih parah. Kearifan lokal dapat dimaksimalkan dengan adanya pengadaan sosialisasi dan edukasi kepada petani di Desa Sembungan. Kearifan lokal dapat menjadi salah satu alternatif untuk meningkatkan pertanian yang ramah lingkungan. Tujuan 
penelitian ini adalah: 1) mengetahui kearifan lokal petani dalam pengelolaan pertanian di Desa Sembungan, dan 2) merumuskan permasalahan dan arahan strategi dari kearifan lokal dalam pengelolaan pertanian di Desa Sembungan.

\section{METODE PENELITIAN}

Penelitian ini dilakukan di Desa Sembungan, Kecamatan Kejajar, Kabupaten Wonosobo (lihat Gambar 1.) dengan menggunakan metode kualitatif. Metode kualitatif dimanfaatkan dalam menjawab kedua tujuan dari penelitian ini dengan memahami dan menafsirkan suatu fenomena melalui pendekatan interpretatif dan naturalistik sesuai dengan kondisi empiris di Desa Sembungan. Dikaji menurut tingkat eksplanasi, penelitian ini dikategorikan sebagai penelitian deskriptif. Hal tersebut diterapkan dengan berbagai tahapan sistematis dalam mendeskripsikan kearifan lokal masyarakat petani dalam pengelolaan pertanian guna mewujudkan pembangunan berkelanjutan. Tahap pertama dimulai dengan menganalisis pengelolaan pertanian berdasarkan kearifan lokal yang diterapkan oleh petani. Tahap kedua dilaksanakan dengan merumuskan arahan strategi dalam menangani permasalahan dalam kearifan lokal di Desa Sembungan.

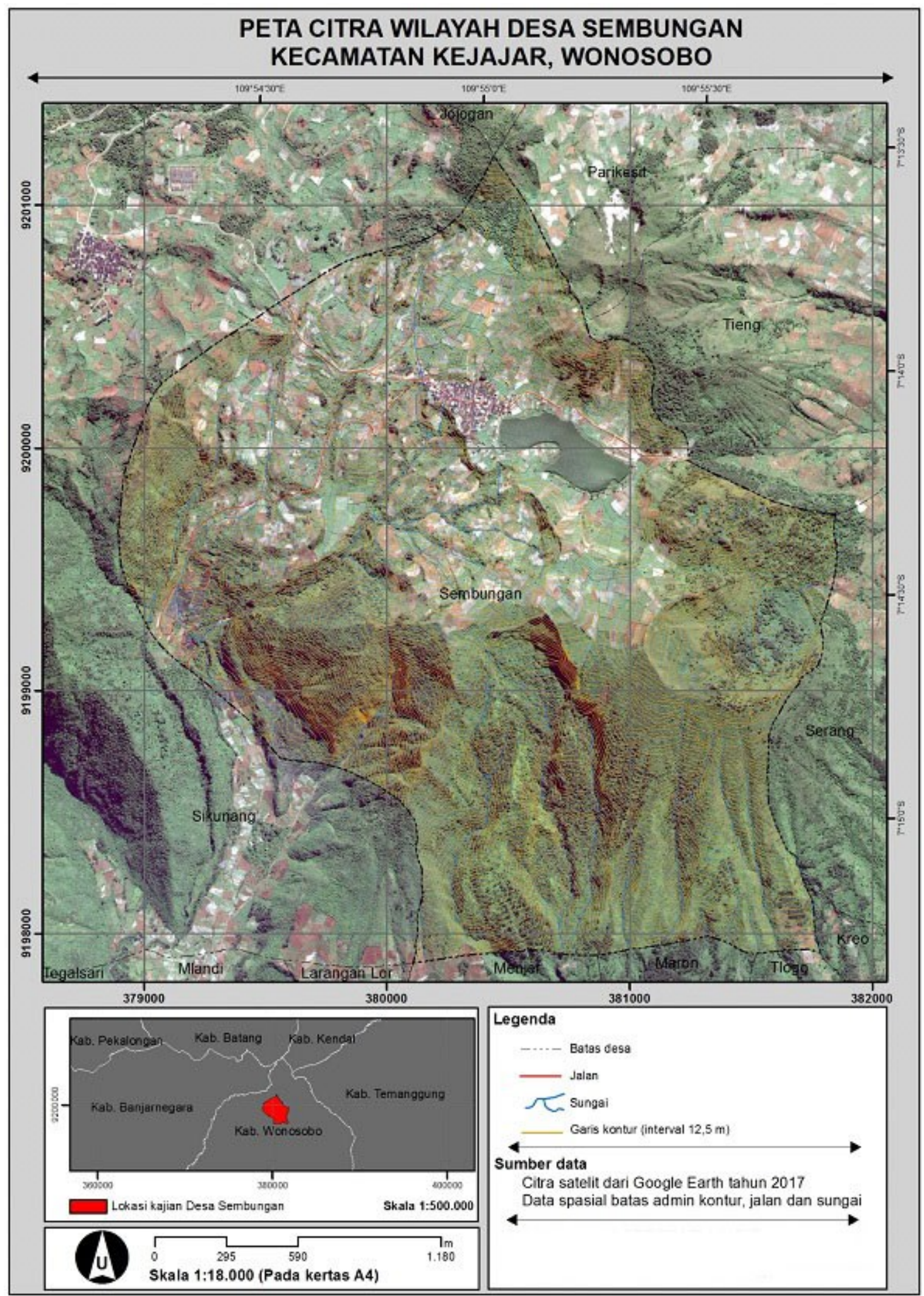

Gambar 1. Peta Lokasi Penelitian 
Data sekunder yang digunakan dalam penelitian ini yaitu data dalam angka, potensi desa, dan statistik pertanian yang bersumber dari Badan Pusat Statistik (BPS). Pengumpulan data dilakukan dengan tiga cara yaitu: 1) wawancara mendalam dengan informan, diantaranya yaitu: ketua kelompok tani, Dinas Kabupaten, dan Dinas Kecamatan; 2) FGD (Focus Group Discussion) dengan dua kelompok tani di Desa Sembungan; dan 3) observasi lapangan untuk validasi hasil FGD dan wawancara mendalam. Analisis data dilakukan berdasarkan tujuan penelitian, tujuan pertama dijawab dengan deskriptif kualitatif terkait dengan kearifan lokal petani di Desa Sembungan dan tujuan kedua dijawab dengan deskriptif kualitatif terkait dengan perumusan arahan strategi dalam menangani permasalahan dalam kearifan lokal di Desa Sembungan.

\section{HASIL DAN PEMBAHASAN}

\section{Jenis Kearifan Lokal dalam Pengelolaan Pertanian}

Masyarakat petani di Desa Sembungan, sebagian besar masih menerapkan sistem pertanian yang bersifat tradisional. Hal ini terlihat dari cara petani dalam mengelola pertaniannya. Sistem tumpang sari ini merupakan salah satu jenis kearifan lokal dari Desa Sembungan yang dapat membantu mengurangi erosi, tetapi hanya segelintir petani yang menyadari akan manfaat tersebut. Pola tanam tumpang sari ini dilakukan dengan menanam variasi tanaman lain dengan akar yang kuat supaya menjadi penahan erosi dan menjaga tanaman utama.

Pertanian di Desa Sembungan terkenal dengan komoditas kentang, karena luasnya lahan pertanian di Desa Sembungan. Lahan pertanian petani sebagian besar berada di bukit yang mengitari desa, sehingga rawan untuk terjadi longsor lahan akibat dari proses pertanian yang dilakukan. Tumpang sari oleh masyarakat petani hanya dijadikan sebagai pengisi lahan yang kosong di pinggir-pinggir lahan tanaman kentang. Tanaman tumpang sari yang ada di Desa Sembungan, diantaranya yaitu: tanaman carica, terong belanda, cabai galapenyo, dan beberapa tanaman kecil lainnya seperti seledri dan bawang merah. Penanaman dilakukan di pinggiran lahan kentang, supaya tidak mengganggu perkembangan tanaman kentang di lahan tersebut.

Masyarakat petani juga mengakui bahwa selain untuk mengisi lahan yang kosong, tumpang sari juga dilakukan dengan mengharapkan hasil dari tanaman yang mereka tanam. Hasil dari tanaman tersebut, meskipun tidak sebesar hasil dari tanaman kentang, tetapi dapat menjadi sedikit tambahan penghasilan bagi para petani. Beberapa pola tanam dari tumpang sari oleh petani dapat dilihat dalam Gambar 2.

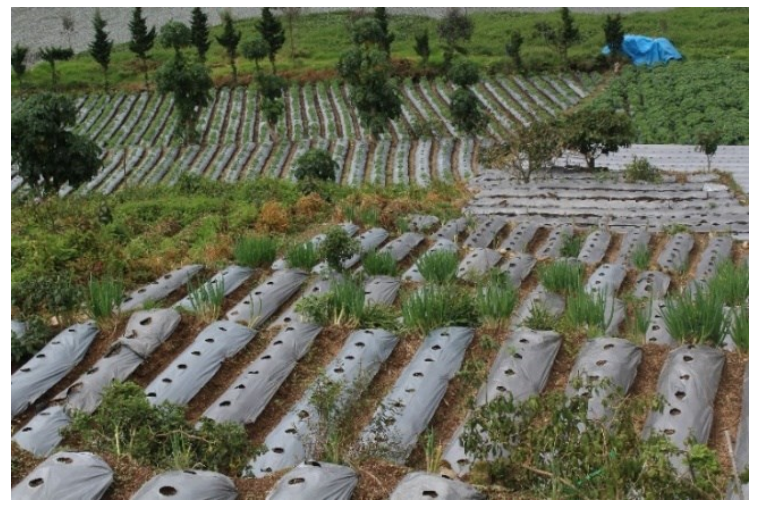

Gambar 2. Tanaman tumpang sari di Desa Sembungan Sumber: Dokumentasi Lapangan, 2017
Para petani yang tergabung dalam kelompok tani telah terlebih dahulu sadar akan pentingnya konservasi untuk menjaga kelestarian lahan pertaniannya. Hal ini menjadi salah satu pemicu bagi mereka untuk melakukan tumpang sari, sebab mereka sadar bahwa pola tanam ini membantu dalam mengurangi besarnya erosi di lahan pertaniannya. Alasan lain yang mendorong mereka melakukan tumpang sari sebagai bentuk konservasi, yaitu karena kesadaran mereka akan menurunnya daya dukung lahan yang dilihat dari tingkat produksi kentang yang menurun.

Jenis kearifan lokal lainnya yang ada di Desa Sembungan ialah gotong royong. Masyarakat di Desa Sembungan masih melaksanakan kegiatan ini, meskipun hanya sedikit yang dilakukan untuk kegiatan pertanian. Kegiatan gotong royong ini biasanya berupa bersih lingkungan di area sungai, mushola dan sekitarnya, dan sebagian besar diikuti oleh pemuda kampung. Gotong royong yang dilakukan untuk kegiatan pertanian, diantaranya yaitu pembuatan jalan menuju ke ladang dengan sistem yang dijadwalkan dan petani yang tidak hadir akan dikenakan denda. Gotong royong juga dilakukan saat pembukaan lahan yang akan digunakan untuk percobaan komoditas baru yang akan ditanam. Kegiatan gotong royong pembukaan lahan ini dapat dilihat dari Gambar 3 .

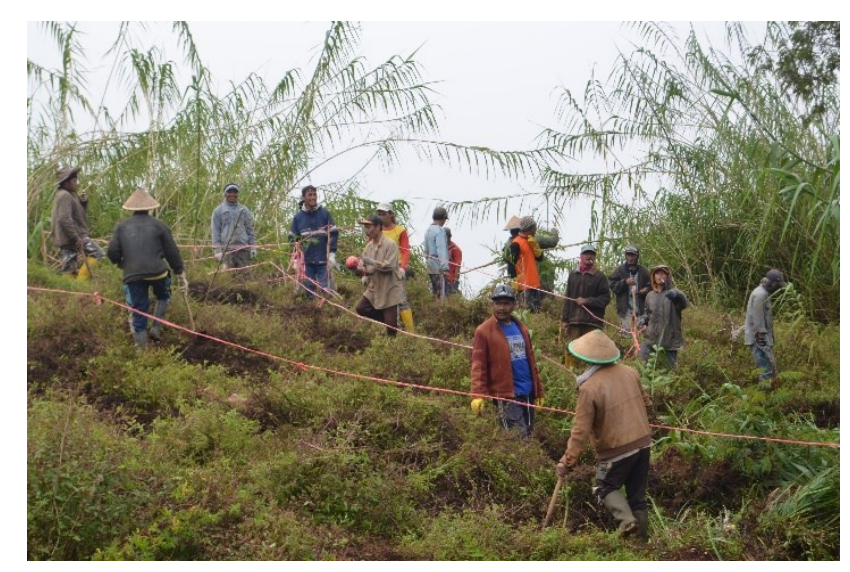

Gambar 3. Gotong royong dalam pembukaan lahan baru Sumber: Dokumentasi Lapangan, 2017

Kegiatan gotong royong dalam pembukaan lahan tersebut, termasuk di dalamnya berupa pembersihan lahan dari tanaman liar pengganggu. Langkah selanjutnya, mereka lakukan seperti langkah awal pada saat memulai lahan pertanian. Para petani juga memulai dengan menanam terong belanda terlebih dahulu, sebelum menanami dengan komoditas baru. Hal ini dilakukan sebagai bentuk kepedulian terhadap lahan dan salah satu upaya konservasi. Gotong royong dalam kegiatan pertanian jarang dilakukan dengan alasan kesibukan para petani dalam mengelola lahan pertaniannya masing-masing. Selain itu, sebagian besar petani yang ada di Desa Sembungan juga memiliki tenaga kerja yang membantu mereka mengelola lahan, dimana tenaga kerja tersebut banyak yang berasal dari luar Desa Sembungan.

Pertanian dalam arti sempit merupakan salah satu kegiatan produksi bercocok tanam dengan memanfaatkan sumberdaya lahan untuk memenuhi kebutuhan hidup (Banowati, 2013). Secara tidak langsung, kegiatan pertanian ini berhubungan dengan alam (yang langsung mengolah sumberdaya alam) dan lingkungan. Keberadaan kearifan lokal dalam pengelolaan pertanian perlu untuk dilestarikan. Keberadaan kearifan lokal penting untuk dilestarikan oleh 
petani agar dapat menjaga keseimbangan dan sekaligus melestarikan lingkungannya. Oleh karena itu, pentingnya mengetahui kearifan lokal dalam pertanian diharapkan dapat menjaga keseimbangan dan kelestarian lingkungan, sehingga tidak menimbulkan kerusakan lingkungan di masa sekarang maupun masa yang akan datang.

Jenis kearifan lokal dalam pengelolaan pertanian dapat bermacam-macam, menyesuaikan dengan kondisi dimana pertanian tersebut dikembangkan. Desa Sembungan yang merupakan daerah pegunungan, umumnya mengenal kearifan lokal dalam pertanian yaitu Nyabuk Gunung. Cara bercocok tanam dengan Nyabuk Gunung ialah dengan membuat teras sejajar dengan garis kontur. Hal tersebut dimaksudkan untuk menghindari terjadinya longsor.

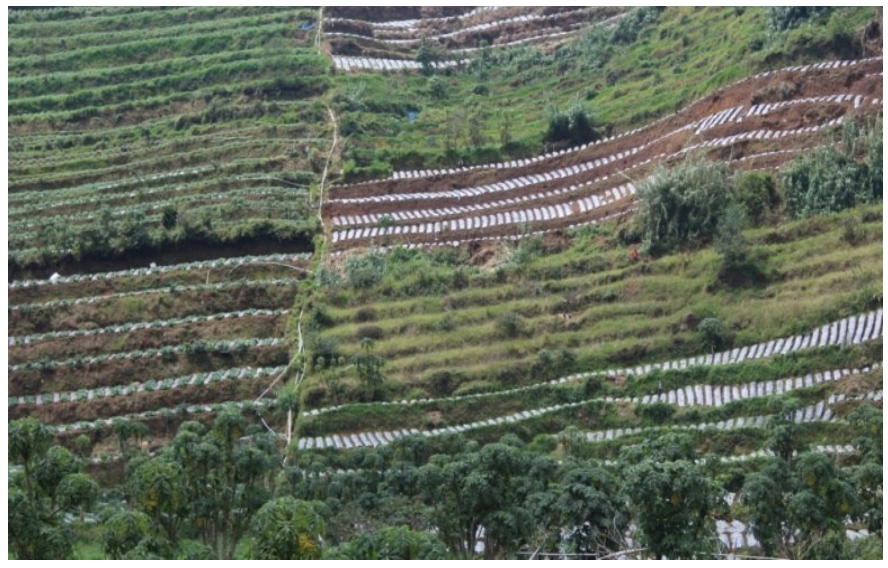

Gambar 4. Pertanian Nyabuk Gunung di Desa Sembungan Sumber: Dokumentasi Lapangan, 2017

Petani di Desa Sembungan memiliki pandangan tersendiri terkait dengan kearifan lokal Nyabuk Gunung ini. Beberapa petani beranggapan bahwa Nyabuk Gunung untuk mengolah lahan pertanian kurang menguntungkan, khususnya di musim penghujan. Ketika musim penghujan, pengolahan lahan pertanian akan lebih banyak dijumpai tidak sejajar dengan garis kontur. Hal ini dimaksudkan agar air langsung turun tanpa terlalu lama terjebak di dalam tanah sehingga kentang tidak terlalu banyak terkena air. Pengolahan lahan pertanian yang sejajar dengan garis kontur membuat tanaman pertanian, khususnya kentang lebih banyak menyimpan air. Kentang tidak bisa terlalu lama menerima air karena akan lebih cepat busuk. Hal yang berbeda ketika musim kemarau, pengolahan lahan pertanian yang sejajar kontur diterapkan oleh petani karena bisa untuk menampung air lebih lama dan banyak. Ketika musim kemarau, sumber air untuk irigasi pertanian berasal dari Telaga Cebong.

Jenis kearifan lokal dalam pengelolaan pertanian yang ada di Desa Sembungan selanjutnya ialah pembuatan selokan dalam. Pembuatan selokan dalam dimaksudkan untuk menampung air yang turun dan tanah yang larut dari proses pengolahan lahan. Selokan dalam ditemui di tiap teras miring pada petak lahan pertanian, terutama pada pengolahan lahan yang tidak sejajar dengan garis kontur. Pembuatan selokan dalam pada lahan pertanian masih tergolong sederhana, yaitu hanya dengan menggunakan peralatan berupa cangkul. Cara membuat selokan dalam yang sudah dilakukan oleh petani yaitu tanah dicangkul hingga menjadi sebuah selokan. Selokan dalam merupakan bentuk konservasi sederhana yang dibuat petani untuk mencegah terjadinya longsor

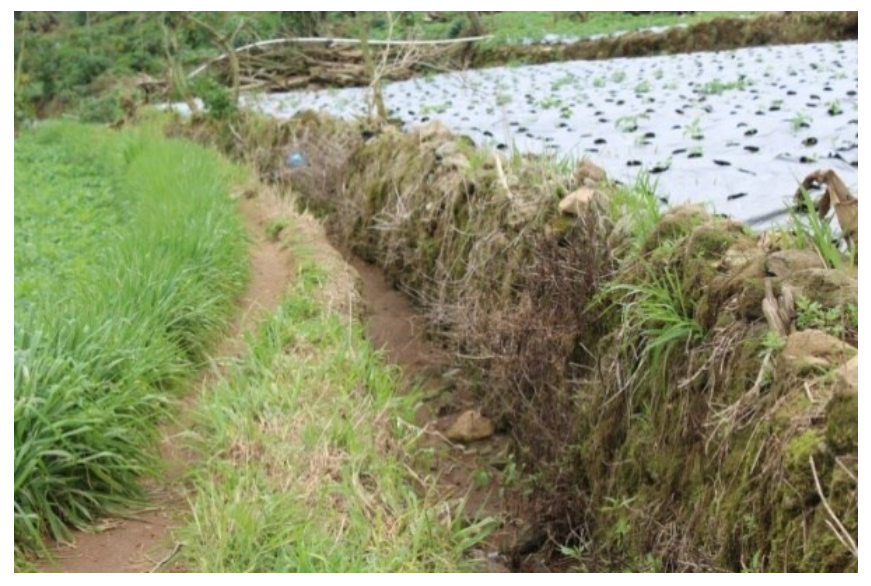

Gambar 5. Selokan dalam di lahan pertanian Sumber: Dokumentasi Lapangan, 2017

\section{Permasalahan dan Arahan Strategi}

Tumpang sari yang dilakukan oleh masyarakat petani, selain sebagai upaya konservasi juga diharapkan hasil tanamannya. Hasil yang diperoleh meskipun tidak sebesar hasil dari tanaman utama (kentang), tetapi dapat sedikit membantu para petani. Akan tetapi, komoditas yang dijadikan sebagai tanaman tumpang sari oleh petani kurang bervariasi dan kurang menguntungkan bagi petani. Oprimalisasi lahan pertanian yang ada dapat dilakukan melalui diversifikasi tanaman yang sesuai dengan karakteristik lingkungan dan potensi produksi tanaman tersebut (Udin dkk, 2009). Desa Sembungan sebagai desa tertinggi di Pulau Jawa, memiliki suhu dan iklim yang sesuai untuk ditanami berbagai jenis tanaman dan menghasilkan nilai jual yang lebih tinggi. Arahan yang dapat diberikan dari kondisi ini diantaranya yaitu Desa Sembungan sebaiknya mengadakan variasi tanaman tumpang sari tetapi harus tetap yang berakar kuat. Variasi ini jika berhasil dilakukan dapat sedikit demi sedikit menggantikan tanaman kentang, karena para petani telah menyadari bahwa tanaman kentang dapat merusak lahan pertaniannya. Penentuan variasi tanaman dapat dilakukan bersama-sama dan dimulai dengan melakukan percobaan penanaman terlebih dahulu. Kesempatan ini harus dilakukan dengan baik mengingat kondisi iklim yang mendukung untuk berbagai jenis tanaman dengan harga jual yang tinggi.

\section{KESIMPULAN}

Berdasarkan hasil temuan pada penelitian dan analisis serta pembahasan, maka dapat ditarik kesimpulan bahwa kearifan lokal dalam pengelolaan pertanian di Desa Sembungan ada 4 macam yaitu: (a) Tumpang Sari: pola tanaman tumpang sari pada pertanian di Desa Sembungan dilakukan dengan menanam variasi tanaman lain dengan akar yang kuat supaya menjadi penahan erosi dan menjaga tanaman utama. Tumpangsari oleh masyarakat petani hanya dijadikan sebagai pengisi lahan yang kosong di pinggirpinggir lahan tanaman kentang, (b) Nyabuk Gunung: Kearifan lokal Nyabuk Gunung tidak sepenuhnya diterapkan dalam pertanian di Desa Sembungan. Beberapa petani beranggapan bahwa Nyabuk Gunung untuk mengolah lahan pertanian kurang menguntungkan dari segi hasil, terutama di musim penghujan karena tanaman pertanian khususnya kentang akan cepat busuk apabila terlalu lama terkena air, (c) Gotong Royong: bentuk kegiatan gotong royong dalam bidang pertanian yang dilakukan oleh petani di Desa 
Sembungan seperti pembuatan jalan menuju ke ladang, pembersihan dan pembukaan lahan untuk ladang pertanian baru, (d) Selokan Dalam: bentuk kearifan lokal dalam pengelolaan pertanian di Desa Sembungan dengan membuat selokan dalam pada area lahan pertanian untuk mencegah terjadinya longsor pada pengolahan lahan pertanian tidak sejajar dengan garis kontur.

Kesimpulan yang selanjutnya ialah terkait permasalahan dan strategi. Permasalahan yang timbul dari kearifan lokal dalam pengelolaan pertanian di Desa Sembungan seperti variasi tanaman tumpang sari yang hasilnya dianggap kurang menguntungkan bagi petani, erosi dan longsor sebagai akibat dari pertanian yang tidak sejajar garis kontur, dan aliran dari selokan dalam yang dapat mencemari telaga. Strategi yang tepat dari permasalahan tersebut ialah perlunya variasi tanaman tumpeng sari yang berakar kuat, perlunya edukasi kepada petani mengenai pentingnya pengelolaan pertanian dengan Nyabuk Gunung, perbaikan infrastruktur selokan dalam serta edukasi dan pelatihan pada petani mengenai tindakan konservasi yang baik dalam pertanian.

\section{UCAPAN TERIMA KASIH}

Penelitian ini merupakan bagian dari Kuliah Kerja Lapangan III Blok 1 Geografi Lingkungan 2014 tahun 2017 dengan tema "Analisis Sumberdaya Lingkungan dan Wilayah”. Pertama-tama kami ucapkan terimakasih kepada Allah SWT karena dengan rahmat dan hidayahnya, penelitian ini bisa terselesaikan dengan baik. Selanjutnya kami ucapkan terimakasih kepada masyarakat dan pemerintah Desa Sembungan yang telah mengizinkan kami untuk melakukan penelitian, Kelompok Tani Maju Bareng Al Hikam dan Sumber Tani sebagai objek dalam penelitian kami, Dinas Pangan, Pertanian dan Perikanan Kabupaten Wonosobo, Penyuluh Pertanian Kecamatan Kejajar, masyarakat petani Desa Sembungan, Bapak dan Ibu Dosen Pembimbing Kuliah Kerja Lapangan III atas bimbingan dan ilmu yang telah diberikan kepada kami, serta seluruh teman-teman Blok 1 Geografi Lingkungan 2014.

\section{DAFTAR PUSTAKA}

Arbangiyah, Raudhotun. (2012). Perubahan Pola Pertanian Rakyat di Desa Sembungan Dataran Tinggi Dieng (1985-1995). Skripsi. Depok: Universitas Indonesia.

Badan Pusat Statistik. (2017). Wonosobo Dalam Angka Tahun 2017. Wonosobo: BPS Press.

Banowati, Eva dan Sriyanto. (2013). Geografi Pertanian. Yogyakarta: Ombak.

Geertz, C. (1989). Abangan, Santri, Priyayi dalam Masyarakat Jawa. Terjemahan. Jakarta: Pustaka Jaya.

Sadali, M. I. (2018). Ketahanan Pangan Berkelanjutan di Kabupaten Sukoharjo. JURNAL GEOGRAFI, 10(1), 86-97.

Syarief, R., Sumardjo, Kriswantriyono, A., \& Wulandati, Y. P. (2017). Pengembangan Ketahanan Pangan Melalui Pemberdayaan Masyarakat di Kawasan Rawan Konflik Timika Papua. Jurnal Ilmu Pertanian Indonesia, 22 (3), 163171.

Udin, K., Muta'ali, L., \& Kurniawan, A. 2009. Pola Penghidupan Masyarakat di Daerah Perdesaan pada Strata Rumahtangga yang Berbeda. Jurnal Majalah Geografi Indonesia, 22(2), 176188. 